\title{
Principles, Objectives and Therapeutic Measures in Dento-alveolar Malalignment in the Period of Growth
}

\author{
AMELIA SURDU ${ }^{1}$, RAMONA FEIER ${ }^{1 *}$, MADALINA MATEI ${ }^{2 *}$, MARIUS MARIS $^{3 *}$, CORINA CIUPILAN $^{4}$, CRISTIAN ROMANEC $^{1}$ \\ ${ }^{1}$ Grigore T. Popa University of Medicine and Pharmacy, Faculty of Dental Medecine, 16 Universitatii Str., 700115, Iasi, \\ Romania \\ ${ }^{2}$ Dunarea de Jos University of Galati, Faculty of Medicine and Pharmacy, 47 Domneasca Str., 800008, Galati, Romania \\ ${ }^{3}$ Titu Maiorescu University, Faculty of Dental Medicine, 67A Gheorghe Petrascu Str., 031593, Bucharest, Romania \\ ${ }^{4}$ Grigore T. Popa University of Medicine and Pharmacy, Faculty of Medecine, 16 Universitatii Str., 700115, Iasi, Romania
}

\begin{abstract}
The harmonious psycho-somatic development of the human body, implicitly the sanogenesis of the dentomaxillary apparatus, is the subject of major concerns highlighted by numerous socio-economic actions and of prophylactic and curative medicine, planned and directed. In this context, the problems regarding the etiopathogenic, clinical and therapeutic particularities of the dento-alveolar disharmony through the dentoalveolar incongruity during the growth period, are greatly actual, precisely because of the increasing frequency of this anomaly, especially due to the dento-implications, paradontal, occlusal, aesthetic, masticatory, dishomeostatic and psycho-social, which they generate. Dento-alveolar disharmony with incongruence, is characterized by the disproportion between the size of the teeth and the size of the alveolar arches, aspect also known as dental clogging or disarming - crunching jaw. The various and numerous causes, the diversity of the board clinical associations and especially the association of dental crushes with common clinical signs and other dento-maxillary abnormalities, especially during this period of morphological and functional modeling, require a certain clinical and therapeutic discernment, careful observation, in order to diagnose correctly, completely and obviously the recommendation and individualization of the most appropriate therapeutic solutions. A number of 17 subjects with age limits of 6.6-17 years were investigated, presenting various clinical forms of dento-alveolar disharmony with incongruence, with the distribution of sexes being: 8 girls and 9 boys. The prognosis is most often unfavorable. Diagnosed late, in permanent dentition, involves complex, more laborious, surgical-orthodontic long-term treatments.
\end{abstract}

Keywords: dento-alveolar disharmony, incongruence, dento-maxillary anomalies

Phylogenetic evolution can be included among the etiological factors of dento-maxillary disorders such as proximal tooth decay, dento-alveolar incongruence or different congenital malformations of the face and neck. The value and interpretation of the genetic factor in the development of the dento-maxillary apparatus cannot be appreciated without knowing the phylogenetic evolution[1-3]. The somatic development programme, which also includes the dento-maxillary apparatus, is gained by organisms during their phylogenetic evolution and is transmitted hereditary to the descendants of the same species and partially it is realized during the ontogenetic development, the environmental factors continuing to influence this system.In this regard, the phylogenetic evolution can be considered as a pathogenic factor of the maxillary dental abnormalities, and at the same time can be an indicator of prospecting the maxillary form to the man's future with possible abnormalities[4-6]. During the phylogenetic evolution the morphology and the cellular and tissue functions do not undergo changes, so that the human has a biological background with the years and the slopes from the simplest organized to the most evolved. In contrast, organs, devices and systems have undergone various specific differences. Cephalic morpho-functional changes that occur during human phylogenetic evolution are performed at different rates, even within the same populations. The rate of phylogenetic reduction of the dental-maxillary apparatus is faster in some people, so dento-alveolar disharmony with incongruity, alveolar retropositions are considered "progressive phenomena ${ }^{\pi}$ because they bring "the new " but they are not always a favorable element of human life.From the morpho-functional phylogenetic changes of the dento-maxillary apparatus are included: dental, alveolar, phylogenetic changes, changes in jaw development and in their position of implantation based on the skull. The alveolar processes have an independent development compared to the other elements of the dento-maxillary apparatus, certain genes in the hereditary dowry coordinate their growth and development according to a certain scheme that has been modified phylogenetically.

\footnotetext{
*email:dr.ramonafeier@yahoo.ro,madalina.matei@yahoo.com,marius@drmaris.ro
} 
Within the ontogenetic evolution we distinguish: growth, development and modeling. The four elements of the dentomaxillary apparatus, represented by: the base of the skull, maxillae, alveoli and teeth, have their own rhythmic, genetically programmed development, which can be influenced by biomechanical means in growth period or by general endocrinemetabolic means.In the etiology of dento-alveolar disharmony with incongruence, regardless of the clinical form, we find general and local causes, which throughout ontogenesis can influence both bone support and teeth [7-9].

The phylogenetic reduction of the alveolar arches faster than the teeth is due to the progressive emergence of a toothmaxillary imbalance of genetic origin through the crossing and mixing of the population at regional level, then continental and worldwide over the centuries.

The size and morphology of the teeth is not influenced by the functional request, but retains the genetic model. Experimental animal studies have also shown that in ontogeny, the facial size of the jaw and of the masticatory muscles depend on the degree of use of the masticatory apparatus. The functional factor with influence on to the component parts of the masticator, it is a mechanism that use or neutralization can play a role in natural selection.

The size of the teeth is not affected by the environmental influences to the same extent as in the rest of the toothmaxillary apparatus, being under direct genetic control. There is a delay between the selection and the own genetic changes. Therefore, the teeth still remain at the usual dimensions [10-12].

Disorders regarding the development of the alveolar arches are the most frequent and are due to a phylogenetic factor that results in the disproportionate dimensional reduction of the alveolar arches relative to that of the teeth. This reduction is not proportional, because the growth factors that drive it are different [13-15]. The reduction of the alveolar arches can also be done during the ontogenetic life under the influence of the pathological factors due to the neuroendocrine and metabolic disorders that influence the quantitative, directional or rhythmic growth of the alveolar arches and the eruption of the teeth. Thus, the dento-alveolar disharmony with transient incongruity appears. In the same etiological framework, the permanent incisors larger than the temporary incisors and the temporary molars larger than the premolars can be pointed out simultaneously; discrepancy between bone and dental age. The lack of parallelism between the biological and dental age leads to dento-alveolar disharmony with inconsistency considered transient, because there is the possibility of self-regulation as the alveolar arches reach their normal limits [16-18].

Another general cause, but also local, with the obvious adverse influence on the bone system is the infectious processes. They act on increasing the alveolar process by the selective destruction of an area of theogenic bone activity, the alveolar arches thus developing insufficiently while the teeth are exerted by these influences.Local mechanical or traumatic causes that act on the growth areas can reduce or stop the growth of cartilages or sutures. It is known the adverse effect of the temporo-mandibular ankylosis on the mandibular growth as well as the consequences of bone traumas in children with possible abrupt stopping of growth [19-21].

Dento-alveolar disharmony with incongruity can be determined by the pressure exerted by the wisdom tooth when the lack of space erupts obliquely [22-24].

In the multiple extractions there are disturbances in the development of the arches in all directions: narrowing, shortening and even infraction, if the extractions were made before the premolars reach the occlusion plane. Dentoalveolar disharmony with incongruence may also occur as a result of the existence of a macrodence, which may be limited to a group of teeth or a single tooth (when the incisors exceed $35 \mathrm{~mm}$ ). Dental position and seat abnormalities are noted. The occurrence of supranumerated teeth included or erupted, also causes a tooth-alveolar disharmony with incongruity/malposition. The association of growth disorders of alveolar arches and tooth eruption determines primary tooth-alveolar incongruence. Dento-alveolar disharmony with incongruity presents a great diversity of clinical pictures whose diagnosis involves difficulties especially in the mixed dentition [25].

The clinical examination is relevant in dental, occlusal and periodontal aspects. Dental signs vary with age: before the age of 6 , so at the temporary dentition the lack of tremors between the incisors can be considered a presumption sign regarding the possible lack of space for permanent incisors, much larger; at 7 years, the permanent central incisors erupt, occupying the space of the central and temporary sides that they mobilize. The lateral incisors without space, will erupt rotated or in ectopic positions. At this age we also find another characteristic sign, namely M 1 - lack of space - in eruption being, it resorbs the distal root of M 2 temporarily which it mobilizes, taking - and instead, between the age of 8 years old and 10 years incongruity occurs in malpositions of the incisors consisting of revolutions, overriding, inclusions. In other cases misaligned incisors appear, lateral incisors but distal face come into contact with M 1 temporar. It will be already installed congruence because the canine teeth will no longer take place on the arch. During all this period the premature extraction of the temporary M 2 will be followed by the medial inclination of the permanent M 1 and the reduction of the space in the support area; at 11-12 years old, there is insufficient space for the eruption of the last 
permanent teeth on the arch. Therefore, the canines will generally erupt ectopically, in the vestibular or palatal position, while PM 2 at the lower arch usually erupts in the lingo-position or remain semi-included[26]. The clinical situation may be unified or bilateral, either due to a time lag between the eruption of the right and left counterparts, either due to the early extraction or, to the important unilateral destruction by caries of the temporary molars, which entails on a single half arch a permanent mesialisation of the permanent molars leading to a lack of marked space on this side. In the unilateral migrations and crushes we often encounter a deviation from the midline; dento-alveolar disharmony with incongruence may occur later with the eruption of the second molar or even later at 16-20 years when the third molar erupts (posterior disharmony). Dento-alveolar disharmony with incongruence can cause various occlusion disorders. We notice premature contacts between the malpositioned antagonists that lead to deviations of the midline $[27,28]$.

The most characteristic and most important occlusal sign is the modification of the sagittal articulation of M 1.

From the multitude of significant complementary examinations within the dento-alveolar incongruence are the following: the study of the gypsum models, the radiological examination, the functional examination. The clinical forms of dento-alveolar incongruence are: dento-alveolar disharmony with primary incongruence (with macrodentition) - the basic clinical signs are macrodentition and insufficient space for the aligned eruption of the teeth; dento-alveolar disharmony with incongruence secondary to alveolar disharmony - the lack of space in this clinical form is due to alveolar disharmony, namely-endoalveolia and retroalveolia; dento-alveolar disharmony secondary to anomalies of development of the dental blade ( rotations, malpositions, ectopias, supernumerary teeth) ; dento-alveolar disharmony with secondary incongruence to caries and early extractions in the support area - is very common, it occurs due to loss of approximate coronary substance or premature extraction of a temporary tooth resulting in mesialisation and distalization of neighboring teeth with asymmetric character ; transient dento-alveolar disharmony - it can be installed by the simultaneous presence on the arch of permanent incisors larger than the premolars, it can also be installed due to the mismatch between the rate of skeletal and dental maturation, in the sense of a bone delay, a situation that makes the jaws too short. it cannot allow the aligned eruption of the teeth. The prognosis of tooth-alveolar incongruence is unfavorable.The treatment of dentoalveolar disharmony with incongruence aims at obtaining a functional and physiognomic optimality. The possibilities and limits of the orthodontic treatment are conditioned by the shape and size of the basal bone of the two jaws, genetically determined and which cannot be modified by treatment. If we accept as possible the influence directional of the alveolar arch, parallel to the muscular rebalancing, we must not forget that if under the action of a mechanical factor the alveolar arch will not commensurate with the size and shape of the basal bone, recurrence will occur [29,30].

If theoretically it is possible to act on the amount of growth of a bone, this is only done in a very small quantity and provided that the growth areas are active; it is not possible to permanently change the direction of growth of the jaws than by changing the static-dynamic tone of the neighborhood musculature. A provisional and artificial change of the direction of growth is obtained, which can disappear with the termination of the action element; the bone tissue with growth period once completed can be modified only by individual surgery [31,32].

The treatment of dento-alveolar disharmony with incongruence must be individualized according to the age of the patient: a prophylactic and early treatment in the temporary dentition; a normal treatment in mixed dentition; a late treatment in permanent dentition.

The prophylactic and early treatment aims to influence, as much as possible, the individual process of growth in quantitative aspect but especially of the rhythm of unfolding during the two growth periods at 8-9 years of age and 10-11 years old.

After the completion of the treatment itself, regardless of the method used, the period of containment (4-6 months), in order to consolidate the results and to achieve a functional rebalancing, thus preventing the possibilities of recurrence.

Normal treatment is for the second period of mixed dentition and the definitive period when the anomaly is already constituted as a clinical entity.

During the period of permutation of the lateral teeth under the direct action of the surface contact of the plate on the vault and the alveolar lateral slope, the permanent buds are moved outward without their axial direction being affected. The lateral permanent teeth will erupt in an extended ridge and with root growth creates their own alveolus. The risk of recurrence is very low.

The treatment of a certain form of dento-alveolar disharmony with incongruence through a preliminary programme of dental extractions plays an important role in orthodontics, when it is concluded that the growth of the facial mass is inadequate and the post-extraction displacement of the teeth is controlled and guided by processes. They are indicated only for arches with a deficient structure with little chance of reaching the normal dimensions and proportions.

Late treatment is applied during the definitive dentition after 12 years, when the tooth-alveolar anomaly is already established, the apical bases are reduced and the Pent index shows a minus of 6-10 mm, keeping all dental units with the 
displacement of the bones of a bone support, means total failure, because the teeth do not stay in the new position if they have a normal relationship with the basal bone.

In such clinical situations, the place of the directed extraction is the curative extraction associated or not with the orthodontic treatment, which will solve the dimensional harmony between the dental arches.

\section{Experimental part}

\section{Material and method}

Without minimizing the major significance of the skeletal factor in the dento-maxillary adjustments, the dento-dental and dento-alveolar relationships remain undoubtedly within the occlusal and dento-maxillary homeostasis. Dento-alveolar incongruence imposes the need for a careful systematization of each clinical picture, with what is particular during the growth period, especially during the period of mixed dentition, thus offering the possibility of an early diagnosis and even the prophylaxis of this disharmony. Undiagnosed and treated on time, are taken over by permanent dentition, in which the clinical forms worsen, requiring a complete and long-term specialized treatment. Were investigated a total of 17 subjects with chronological age limit from 6.6 to 17 years, presenting various clinical forms of disharmony dental alveolar incongruence, the gender distribution is: 8 girls and 9 boys.

\section{Results and discussions}

In interpreting the studied factual material, we considered the entire etiopathogenic and clinical complexity of the dento-alveolar disharmony with incongruity, respectively the entities: primary dento-alveolar incongruence; secondary tooth-alveolar incongruence; their association; iatrogenic dento-alveolar incongruity; transient dento-alveolar incongruity. Regarding the established therapeutic behavior, we focused in particular on biomechanically active therapeutic means and adjuvant surgical treatment. Dento-alveolar disharmony with insufficient space for the normal eruption of permanent teeth, pregnant expression of tooth-alveolar incongruence - between the volume of teeth and alveolar arches - is very common, with a marked aggravating evolutionary potential, so it can be considered as a central problem of the current ortho-gnato-pedodontics. From the analysis of the presented cases, correlated with the synthesis of the data from the consulted literature, a complex range of etiopathogenic, clinical and therapeutic features of this anomaly results, whose practical resonance is found during the growth period and especially during the period of mixed dentition, which requires individualization as much as possible early anatomical-clinical, functional, complete and complex diagnosis.

The prognosis is most often unfavorable. Poor oral hygiene due to lack of self-cleaning and incorrect tooth brushing, favors the appearance of the approximate cavities and the periodontal damage to the upper and lower frontal group. Physiognomic disorders create inferiority complexes. Disharmony and its consequences are taken over and aggravated by permanent dentition. Given the frequency, the morpho-functional implications, it is mandatory for the orthodontist and omnipractician to make the prophylaxis and early diagnosis of the various clinical forms of dento-alveolar disharmony with incongruence in the mixed dentition. The child will thus benefit from dental-periodontal and dental-alveolar prophylaxis and timely applied treatment with simple, accessible means.

\section{Conclusions}

Diagnosed late, in permanent dentition, it involves complex, more laborious, surgical-orthodontic long-term treatments. In the practical materialization of this desirable the active dental dispensary, in the condition of a thorough professional training and instituted from the anti-preschool period, ensures the most suitable framework for primary and secondary prophylaxis of this complex anomaly.

\section{References}

1.ABDULLAH, M.S., ROCK, W.P., Assessment of orthodontic treatment need in Malaysian children using the IOTN and DAI indices.Community Dent Health, 2001.

2.ALATRACH, A.B., SALEH, F.K., OSMAN, E., The prevalence of malocclusion and orthodontic treatment need in a sample of Syrian children. European Scientific Journal, 10(30), 2014.

3.AZNAR, T., GALAN, A.F., MARIN, I., DOMINGUEZ, A., Dental arch diameters and relationships to oral habits. Angle Orthodontist, 2006.

4.BĂICUS, C., Medicina bazata pe dovezi, Editura Medicala, Bucuresti, 2007.

5.BISHARA, S.E., Facial and dental changes in adolescents and their clinical implications. The Angle Orthodontist, 70(6), 471-483, 2000.

6.COCÂRLĂ, E., DRAŞOVEAN, A., Studiu asupra corelaţiilor dintre anomaliile dento-maxilare si tipul de respiraţie, Universitatea de Medicină şi Farmacie"Iuliu Hatieganu" Cluj-Napoca, 2010. Cocarala Elvira, Stomatologie pediatrică, Editura Medicală Universitară Iuliu Hatieganu, Cluj Napoca, 2000. 34

7.BOBOC, G., Aparatul dento-maxilar Formare și Dezvoltare, Editura Medicala, Bucuresti, 2003. DAnila I, Dentistica Preventiva Editura Didactica si Pedagocica, Bucuresti, 2005. 
8. CIURCANU, O.E., FORNA, D.A., POPA, C., SCUTARIU, M.M., Implementation of methods of loco-regional anesthesia in dental surgery. RJOR, 2017 Volume: 9, 4, Pages: 120-127

9.DĂNILĂ, I., ZETU, S.N., Studiul clinic al malocluziilor si necesarului de tratament ortodontic la populaţia tanara din Romania, Universitatea de Medicina si Farmacie GrigoreT.Popa Iasi Stomatologie Generala Disciplina: Preventie Oro - Dentara, 2014.

10.DĂNILĂ, I., HANGANU, C., PETERSEN, P.E., AMARIEI, C., PODARIU, A., SAMOILA, A., Changes in oral health behavior, knowledge and atitudes of mothers and schoolteachears in Romania from 1993 to 2003. Community Dental Heath,20;177-198, 2003.

11.DASCĂLU, I.T., Contributii la studiul anomaliilor de clasa a III a Angle, Universitatea de Medicina si Farmacie Grigore T.Popa Iasi, 2010.

12.DASCĂLU, I.T., Etiopatogenia anomaliilor dento-maxilare clasa a III-a Angle, Revista Medicala Romana - volumul LVI, nr. 1, 2010.

13.DOROBĂT, V., si colab.: Epidemiologia anomaliilor dento-maxilare la varsta de 7 ani. Revista de Ortodonțieşi ODF 1 (2): 2-7, 2000

14.DOROBĂT, V., STANCIU, D., Ortodontie si ortopedie dento-faciala, Editura medicala, Bucuresti, 2011. Dorobat V, Dascalu IT, Contributii la studiul anomaliilor de clasa a III a Angle, Universitatea de Medicina si Farmacie Gr. T. Iasi, Facultatea de Medicina Dentara, 2010.

15.DOROBĂȚ, V., STANCIU, R.P., Contributii la studiul anomaliei clasa II/2 Angle, Universitatea de Medicina si Farmacie Gr. T. Popa Iaşi, Facultatea de Medicina Dentara, 2013.

16.DUMITRACHE, M.A., SFEATCU, I.R., BUZEA, C.M., DUMITRASCU, L.C., LAMBESCU DG. Concepte si tendinte in sanatatea orala. Ed. Universitara Carol Davila, Bucuresti, 2009.

17.LAGANÀ, G., MASUCCI, C., FABI, F., BOLLERO, P., COZZA, P., Prevalence of malocclusions, oral habits and orthodontic treatment need in a 7-to 15- year-old schoolchildren population in Tirana. Progress in orthodontics, 14(1), 12, 2013.

18.GRABER, T.M., VANARSDALL, V., Orthodoctics principles and techniques, Fourth edition Elsevier Mosby, 2005.

19.HANGANU, S.C., DANILĂ, I., Stomatologie comunitara, Ed. Tehnica-Info, Chisinau, 2002.

20.IONESCU, E., MILICESCU, V., Notiuni de Tehnica Ortodontica, Ed. Cerma, Bucuresti 2006.

21.IONESCU, E., Anomaliile dentare, Cartea Universitara Bucuresti, 2005.

22.LUX, C.J., DUCKER, B., PRITSCH, M., KOMPOSCH, G., NIEKUSCH, U., Occlusal status and prevalence of occlusal malocclusion traits among 9- year-old schoolchildren. European Journal of Orthodontics, 2009.

23.CIURCANU, O., CIUPILAN, C., SALCEANU, M., MELIAN, A., FORNA, D.A., SCUTARIU, MM., Particularities of the dental treatment strategy in geriatric patients, RJOR, 2018 Volume: 10, 1, Pages: 108-113,

24.TEODORESCU, M., SCHACHER, L., ADOLPHE, D.; et al.Experimental and Theoretical Investigations in Polyamide Spin-Coated Thin Films, Mat. Plast.,50, no. 3,2013 , p. 225

25.DASCALU, C.G., ANTOHE, M.E., GOLOVCENCU, L., et al.,Interaction Schemes for the Analysis of Combined Action of Risk Factors,2017 IEEE International Conference on e-health and Bioengineering Conference (EHB) Book Series: E-Health and Bioengineering Conference, 2017, Pages: 462-465

26.MAGHIAR, T.T., CUC, E.A., Evaluarea Particularitatilor Epidemiologice ale anomaliilor dento-maxilare in perioada dentitiei mixte, Universitatea din Oradea, Facultatea de Medicina si Farmacie, 2014..Proffit WR, Fields HW, Sarver DM, Contemporary Orthodontics, Mosby Com., 2007.

27.SCUTARIU, M.M., DANILA, V., CIUPILAN, C., CIURCANU, O.E., Semiology of the Pain Syndrome - Identifying the Ideal Methods of Locoregional Anesthesia Based on Their Rationale and Features; Rev. Chim., 68, no. 10, 2017, p. 2373

28.SPINEANU R, TODOR BI, Contributii la studiul prevalentei anomaliilor dento-maxilare in zone miniere din Apuseni, Universitatea din Oradea, Facultatea de Medicină si Farmacie, 2014.

29.DUMITRESCU, A. L., DOGARU, C. B., DUTA, C., et al.,Impact of emotional neglect and self-silencing on body mass index and oral health behaviors: a structural equation model analysis in undergraduate students, International Conference Psychology and The Realities of the Contemporary World (Psiworld 2013), 4TH Edition Book Series: Procedia Social and Behavioral Sciences Volume: 127,2014, Pages: 363-367

30.SCUTARIU, M.M., MACOVEI, G., CIURCANU, O.E.L., SURDU, A., FORNA, N. C., Contributions to the characterization of biocenosis complex of the ecosystem in the oral cavity, The Medical-Surgical Journal, 2017, 121, vol. 4, pg. 801-805

31. SPINEANU, R., ISTOC, A., Anomalii ale dentatiei permanente la copiii si adolescenţii din judetul Bihor, Universitatea din Oradea, Facultatea de Medicina si Farmacie, 2014.

32.STANCIU, D., BEURAN, I., Factorii etiopatogenici in sindromul ocluziei deschise. Analiză retrospectiva, Disciplina de Ortodontie si Ortopedie Dento-Faciala, Universitatea de Medicina si Farmacie Carol Davila, Revista Medicală Romana - volumul LXI, nr. 4, 2014.

Manuscript received: 06.02.2020 